\title{
Cardioprotective Effect of Kelor (Moringa oleifera) Leaf Ethanolic Extract against Doxorubicin-Induced Cardiotoxicity in Rats
}

\author{
Fikriansyah $^{1}$, Mentari Widiastuti ${ }^{1}$, Nindi Wulandari ${ }^{1}$, Prisnu Tirtanirmala ${ }^{1}$, and \\ Retno Murwanti ${ }^{2}$ \\ ${ }^{1}$ Cancer Chemoprevention Research Center, Faculty of Pharmacy, Universitas Gadjah Mada, Yogyakarta, Indonesia \\ ${ }^{2}$ Faculty of Pharmacy, Universitas Gadjah Mada, Yogyakarta, Indonesia
}

\begin{abstract}
The usage of doxorubicin (DOX) as an anticancer drug in cancer patient may cause several side effects. One of that is cardiotoxicity by inducing the expression of nitric oxide synthase which may release nitric oxide (NO) resulting reactive oxygen species (ROS) in the cardiac. DOX needs to be combined with antioxidant since it could supressed ROS in the cardiac and reduce cardiomyopathy. Kelor (Moringa oleifera) is known as the source of antioxidant. This study aim to observe the treatment effects of ethanolic extract of kelor (EEK) on histopathology profile and concentration of NO in rats cardiac. The result from the hematoxylin-eosin staining showed that EEK improved the histopathology profile of rats' cardiac. Compared with the DOX-only treatment, the structure of cardiac muscle cells treated by ethanolic extract of kelor is more well-arranged and the cells' nucleus still visible. Concentration of NO was measured by cardiac puncture method. The result showed that the concentration of NO was decrease in line with increasing dose levels of EEK in combination with DOX. But at rats only given with EEK, the concentration of NO is quite high. In conclusion, EEK could be a cochemotherapy agent by reducing the cardiotoxicity effect of DOX.
\end{abstract}

Keywords : doxorubicin, Moringa oleifera, nitric oxyde, histopathology

\section{INTRODUCTION}

Chemotherapy is a cancer treatment using chemical compounds to suppress or stop the cells proliferation, or cancer cells (cytotoxic). Doxorubicin is one of the chemotherapeutic agents that are considered effective and widely used (Frias, et al., 2009). The use of doxorubicin in cancer therapy have provided some of the irreversible side effects, affect the immune system, hair loss, and cardiotoxicity (Bustova, et al., 2009; Frias, et al., 2009). A study of 399 patients shows that the incidence of heart failure in patients who receive large doses of doxorubicin was more than 18\% (Singal, et al., 2000). Cardiotoxic effects can lead to heart failure, inability of the heart to pump enough blood throughout the body which is due to cardiomyopathy. Cardiomyopathy decrease myocardial function that caused by several factors, one of them is caused by chemotherapeutic agent. Doxorubicin can induce the expression of nitric oxide synthase (NOs), releases nitric oxide (NO) and generates reactive oxygen species (ROS) (Fogli, et al., 2004). Therefore, an innovation is needed to reduce the cardiotoxic effects of doxorubicin.

Co-chemotherapy is a cancer therapeutic strategies by combining a compound with chemotherapeutic agents. Compounds or drugs may increase the therapeutic efficacy and lowering the toxicity of chemotherapeutic agents against normal tissue (Sharma, et al., 2004; Tyagi, et al., 2004).

Selectioning nature compound as cochemotherapy that acts cardioprotector is a prospective opportunities in drug development. One of the plants could be developed is Moringa (Moringa oleifera). Moringa leaves are known containing flavonoids, kaempferol and quercetin.

\footnotetext{
*Corresponding author e-mail: retno_murwanti@ugm.ac.id
} 
Kaempferol were reported that have antioxidant activity not only in vitro but also in vivo (Calderon-Montano, et al., 2011). Previous study proved that Moringa leaf extract can reduce peroxyl radical activity and superoksil (Siddhuraju, 2003). This antioxidant effect may suppress the formation of reactive oxygen species (ROS) that cause cardiomyopathy.

This study was conducted to determine the effect of ethanolic extract of leaves of Moringa (EEK) to the histopathological profiles and levels of NO in the heart of doxorubicininduced rats. Ultimately, this research is expected to be a scientific basis for the development of potential drug innovation and secure as its application to the prevention of cardiovascular disease in patients with cancer of the medicinal plants that can be utilized by the public.

\section{MATERIALS AND METHODS}

\section{Plant collection and identification}

Moringa leaves was obtained from Nologaten, Sleman, Yogyakarta. Moringa leaves was determinated in Department of Pharmaceutical Biology, Faculty of Pharmacy, University of Gadjah Mada. Moringa leaves are cleaned by washing with water and dried with aerated in an open space without being exposed to direct sunlight. Continued drying in the oven with a maximum temperature of $70^{\circ} \mathrm{C}$. After dry, leaves was blended, sieved with a sieve size of B40 to obtain a homogeneous powder size.

The powder was extracted by maceration method with $70 \%$ ethanol. Comparison of powder with solvent was 1:10. The extract obtained then concentrated using a rotary evaporator until the moisture content is less than $10 \%$.

\section{Identification of Flavonoids}

Identification of flavonoid was done qualitatively by thin layer chromatography (TLC). Moringa leaf extract was dissolved in $70 \%$ ethanol and splatted to stationary phase silica gel GF 254 using a capillary tube, after that the development of the mobile phase Butanol: Acetic Acid: Water (3:1:1) was done. Spot detection was done by observation under visible light, UV light $254 \mathrm{~nm}$, and $366 \mathrm{~nm}$. Spray reagent used was Aluminum Chloride.

\section{Animal}

Twenty five female Sprague Dawley rats, old about 60 days, weight about 100 grams obtained from the Animal-Testing Breeding Unit UGM. Rats were placed in separate cages at temperature of $28-32^{\circ} \mathrm{C}, 98 \%$ relative humidity and light set with 12 hours of light and 12 hours of darkness in the ventilated room. Rats fed pellets and drinked water ad libitum. Rats was adapted in a cage trial of Pharmacology and Toxicology Laboratory of the Faculty of Pharmacy UGM, Yogyakarta for one week before being given treatment. Body weight of rats weighed every day during the experiment.

\section{In Vivo Experimental Design}

Animal tests were grouped into 5 groups and the number of rat in each group was 5 . Group I was given DOX at $4.67 \mathrm{mg} / \mathrm{kgBW}$ intraperitoneally once a week, on days 1 and 8 . Group II was given DOX at $4.67 \mathrm{mg} / \mathrm{kg}$ intraperitoneally twice a week on days 1 and 8 , and EEK dose of $500 \mathrm{mg} / \mathrm{kgBW}$ were orally every day for 2 weeks to on days 1-14. Group III was given DOX at $4.67 \mathrm{mg} / \mathrm{kgBW}$ intraperitoneally twice a week on days 1 and 8 , and EEK dose of $1000 \mathrm{mg} / \mathrm{kgBW}$ were orally every day for 2 weeks on days 1-14. Group IV was given EEK at $1000 \mathrm{mg} / \mathrm{kgBW}$ in the solvent CMC-Na $0.5 \%$ orally. Group V as a group without treatment. All groups were treated daily for 14 days. On $15^{\text {th }}$ day, heart rats was taken by surgery to determined cardiac histopathology profiles by hematoxylin and eosin reagent and measured the amount of NO by Griess reagent.

Determination of cardiac histopathological profile was done by attaching the heart tissue in paraffin then cut and placed on object glass. The tissue was given hematoxylin and eosin reagent and observed using light microscopy. Determination of the amount of $\mathrm{NO}$ in the heart was done by enzymatic reactions that convert nitrate to nitrite using nitrate reductase. This reaction is followed by colorimetric detection of nitrate with colored azo product of the Griess reaction. The absorbance products were measured at $533 \mathrm{~nm}$ wavelength light.

\section{Statistical Analysis}

The results before and after the experiment were analyzed by one-way ANOVA 
method followed by the analysis of OneSample Kolmogorov-Smirnov Test and Post Hoc Test.

\section{RESULT AND DISCUSSION}

\section{Cardiac Hystopathology}

In group I (Fig. 1A), there are heart muscle damage characterized by the number of cells without nuclei and hypertrophy cells. In addition, it appears that occured erythrocyte extravasation because the blood vessel is not intact. The composition of the cell is disorganized and both of nuclei and cells size is not uniform. More regularly of cardiac muscle structure cells are demonstrated in groups II and III (Fig. 1B and 1C). Cells still have the nuclei and the size of each cells and nucleus nearly uniform. This suggests that the EEK able to repair heart muscle cells damaged in rats induce doxorubicin, dose dependent. Cardiac histopathology profil shown slightly bad in group IV (Fig. 1D) because many cells missed nucleus. Probably, this condition due to the EEK treatment was combined by DOX with dose $1000 \mathrm{mg} / \mathrm{kgBW}$ is too high. Cardiac histopathological profile looks normally in group $\mathrm{V}$ (Fig. 1E). The size of each cell and nucleus nearly uniform, many cells have nucleus, did not happen erythrocytes extravasation, and blood vessel walls remain intact.

\section{Scoring Level of Cardiac Muscle Damage}

The qualitative profile of cardiac histopathology then was analyzed semiquantitatively by scoring the level of cardiac muscle damage. The more severe the damage, the higher the score (Table 1). The score showed that there is no significant difference between the group treated EEK $500 \mathrm{mg} / \mathrm{kgBW}$ and $1000 \mathrm{mg} / \mathrm{kgBW}$. This suggests that the range of doses used is not wide enough, so it can not be determined the optimal dose for EEK to protect cardiac tissue from damage.

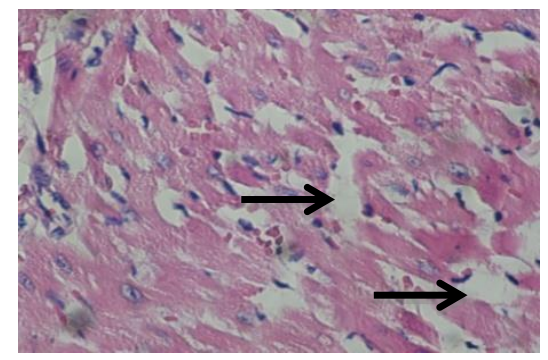

(A)

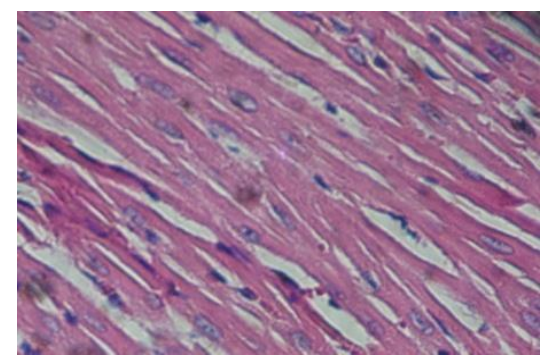

(B)

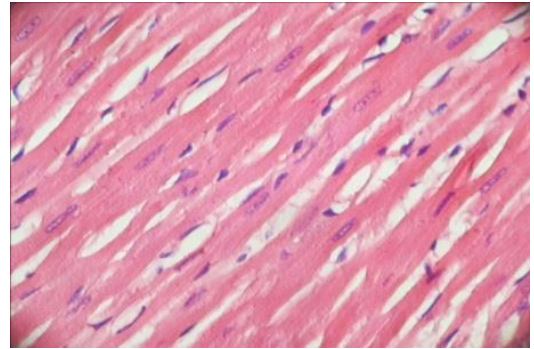

(C)

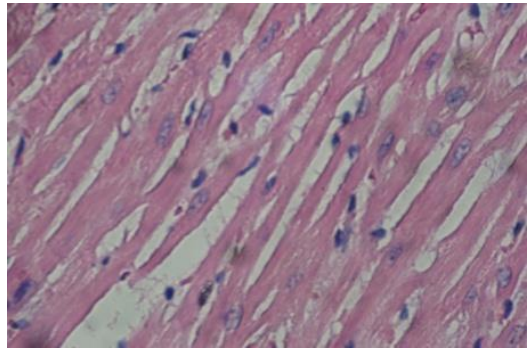

(D)

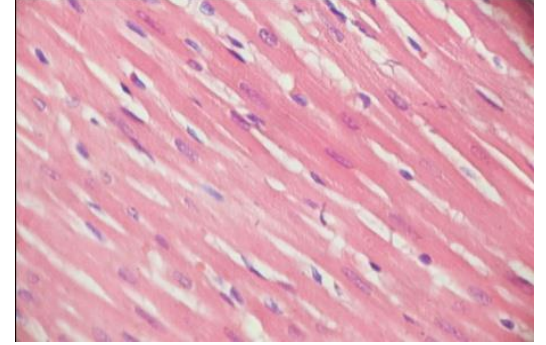

(E)

Figure I. Cardiac histopathology profile caused by doxorubicin and EEK. The heart of animal test were removed during necropsy, and the paraffin preparate of mamae were made to be stained by Hematoxylin Eosin staining as decribed in the methods. Pictures shows the preparate of mammae on group treated with (A) Dox, (B) Dox+EEK 500mg/KgBW, (C) Dox+EEK $1000 \mathrm{mg} / \mathrm{kgBW}$, (D) EEK $1000 \mathrm{mg} / \mathrm{kgBW}$, (E) control. Arrow $(\rightarrow$ ) shows the damage of cardiac muscle. 
Table I. The comparison ofthe antiradical activity of extracts

\begin{tabular}{|c|c|c|}
\hline Group & Score & Mean \\
\hline \multirow{5}{*}{ I } & +3 & \multirow{5}{*}{$3^{*}$} \\
\hline & +4 & \\
\hline & +3 & \\
\hline & +3 & \\
\hline & +2 & \\
\hline \multirow{5}{*}{ II } & +1 & \multirow{5}{*}{ I } \\
\hline & 0 & \\
\hline & +2 & \\
\hline & +1 & \\
\hline & +1 & \\
\hline \multirow{5}{*}{ III } & 0 & \multirow{5}{*}{0.4} \\
\hline & +1 & \\
\hline & 0 & \\
\hline & 0 & \\
\hline & +1 & \\
\hline \multirow{5}{*}{ IV } & 0 & \multirow{5}{*}{0} \\
\hline & 0 & \\
\hline & 0 & \\
\hline & 0 & \\
\hline & 0 & \\
\hline \multirow{5}{*}{ V } & 0 & \multirow{5}{*}{0} \\
\hline & 0 & \\
\hline & 0 & \\
\hline & 0 & \\
\hline & 0 & \\
\hline
\end{tabular}

(*) significantly different with control

\section{ACKNOWLEDGEMENT}

We would like to thank to DP2M DIKTI, Ministry of Education, Republic of Indonesia for granting this research through PKMP 2012.

\section{REFERENCES}

Arafa H.M., Abd-Ellah M.F. and Hafez H.F., 2005, Abatement by Naringenin of Doxorubicin-Induced Cardiac Toxicity in Rats, J. Egypt. Cancer Inst., I7(4), 29I-300.

Bustová, I., 2009, Risk of Cardiotoxicity of Combination Treatment Radiotherapy and Chemotherapy of Locally Advanced Breast Carcinoma Stage III, Klin. Onkol., 22(I), I7-2I.

De Beer, E.L., Bottone, A.E. and Voest, E.E., 200I, Doxorubicin and Mechanical Performance of Cardiac Trabeculae after Acute and Chronic Treatment: a Review, Eur. J. Pharmacol, 4I5(I), I-II.

Fogli, S., Nieri, P. and Breschi, M.C., 2004, The Role of Nitric Oxide in Anthracycline Toxicity and Prospects for Pharmacologic Prevention of Cardiac Damage, FASEB. J., I8(6), 664-675.
Frias, M.A., Lang, U., Gerber-Wicht, C. and James, R.W., 2009, Native and Reconstituted HDL Protect Cardiomyocytes from Doxorubicininduced Apoptosis, Cardiovasc. Res., 85(I), II8-126.

Garner A.P., Paine M.J., Chinje E.C., Ortize P., Strat Ford I.J., et al., 1999, Nitric Oxide Synthases Catalyse the Activation of Redox Cycling and Bioreductive Anticancer Agents, Cancer Res., 59(8), 1929-1934.

Montano, Calderon J.M., Burgos-Moron E., Perez-Guerrero C. and Lopez- Lazaro M., 20II, A Review on Dietary Flavonoid Kaempferol, Mini. Rev. Med. Chem., I I (4), 298-344.

Palmer, R.M., Ashton, D.S. and Moncada, S., 1988, Vascular Endothelial Cells Synthesize Nitric Oxide From L. arginine, Nature., 333(6174), 664-666.

Schildknecht, S., Pape, R., Muller, N., Robotta, M., Marquardt, A., Burkle, A., et al., 20II, Neuroprotection by Minocycline caused by Direct and Spesific Scavenging of Peroxynitrite, J. Biol. Chem., 286(7), 499I-5002.

Sharma, G., Tyagi, A.K., Singh, R.P., Chan, D.C.F. and Agarwal, R., 2004, 
Synergistic Anticancer Effect of Grape Seed Extract and Conventional Cytotoxic Against Human Breast Carcinoma Cells, Breast Cancer Res. Treat., 85(I), I-I2.

Siddhuraju, P. and Becker, K., 2003, Antioxidant Properties of Various Solvent Extracts of Total Phenolic Constituents from Three Different Agroclimatic Origins of Drumstick Tree (Moringa oleifera Lam.) Leaves, J. Agric. Food Chem., 5 I (8), 2। 44-2I55.
Singal, P.K., Li, T., Kumar, D., Danelisen, I. and lliskovic, N., 2000, Adriamycin-induced Heart Failure: Mechanism and Modulation, Mol. Cell Biochem, 207(I2), 77-86.

Tyagi, A.K., Agarwal, C., Chan, D.C.F. and Agarwal, R., 2004, Synergistic Anti Cancer Effect of Silibinin with Conventional Cyotoxic Agents Doxorubicin, Cisplatin, and Carboplatin against Human Breast Carcinoma MCF-7 and MDA-MB468 Cells, Oncol. Rep., I I (2), 493-499. 